\title{
Locating the Weak Points of Innovation Capability before Launching a Development Project
}

\author{
Anne Kallio \\ Lappeenranta University of \\ Technology, \\ Lahti School of Innovation, \\ Lahti, Finland
}

anne.kallio@lut.fi

\author{
Paula Kujansivu \\ Tampere University of \\ Technology, Department of \\ Industrial Management, \\ Tampere, Finland
}

paula.kujansivu@tut.fi

\section{Satu Parjanen \\ Lappeenranta University of Technology, Lahti School of Innovation, Lahti, Finland}

satu.parjanen@lut.fi

\begin{abstract}
Before launching a development project to enhance innovation capability, it is essential to know how innovation capability is comprehended. This paper suggests a procedure to locate the development targets of organizational innovation capability before making decisions on projects. First, from the viewpoint of practice-based innovation, an understanding of the concept of innovation capability is provided. Further, the suggested classification for innovation capability provides a basis for developing the measurement instrument. Finally, to answer the research question of how an innovation intervention should be targeted, this paper uses practical experiences of implementing the procedure in the setting of a single case company.
\end{abstract}

Keywords: development project, practice-based innovation, innovation capability, measurement, questionnaire, survey

\section{Introduction}

Innovation capability has been recognised as a future success factor. Companies are interested in developing their innovation capability, and the research community has developed various methods to assist managers in their development work. There are reported experiences of applying these methods successfully in practice (Kallio \& Bergenholtz, 2011; Parjanen, Harmaakorpi, \&

Material published as part of this publication, either on-line or in print, is copyrighted by the Informing Science Institute. Permission to make digital or paper copy of part or all of these works for personal or classroom use is granted without fee provided that the copies are not made or distributed for profit or commercial advantage AND that copies 1) bear this notice in full and 2) give the full citation on the first page. It is permissible to abstract these works so long as credit is given. To copy in all other cases or to republish or to post on a server or to redistribute to lists requires specific permission and payment of a fee. Contact Publisher@InformingScience.org to request redistribution permission.
Frantsi, 2010).

The literature on development projects defines two major phases: project planning and project execution (Khurana \& Rosenthal, 1997). Project planning of development projects includes choosing the project to work on, setting product and project targets, and putting in place the key resources and mechanisms to accomplish the development effort. The 
project execution phase involves actually carrying the project through to completion (Tatikonda \& Rosenthal, 2000).

However, the success of development projects is not always guaranteed. A lot of projects are carried out that neither lead anywhere nor leave visible traces in the organization. In addition, these projects are rarely reported and published. Why do these projects fail? Are the researchers incompetent? Is the company not skillful enough to implement the results? Development projects are somewhat obligatory in today's business environment. One must keep developing to achieve success. But on what premises are the decisions made on what should be developed? How often does an external researcher present a product, after which a manager makes a go/no go decision based on his/her individual knowledge? This is often the case. Managers make decisions and may lack knowledge of what is the reality in the actual work processes (M. Cohen, March, \& Olsen, 1972).

The concept of innovation capability as such is complex. No existing theory of business or innovation completely explains innovation capability (Koivisto, 2005). However, there is no one truth about what innovation capability actually is. It is essential to understand the viewpoint and comprehension of innovation and the capability to produce innovations in a given company before development projects to enhance innovation capability can be fully designed.

Our approach to innovation as well as innovation capability is practice-based innovation (Ellström, 2010; Melkas \& Harmaakorpi, 2012). Harmaakorpi and Melkas (2012) have used a division where Mode 1 knowledge generation is based on a STI (science-technology-innovation) model and Mode 2 knowledge generation is based on the processes of doing-using-interacting (DUI) (for the definitions of STI and DUI, see Jensen, Johnson, Lorenz, \& Lundvall, 2007). Innovation capability in the context of practice-based innovation is further based on the customerand employee-driven innovations that are born (also) in non-R\&D environments.

The research question of this paper is: How should an innovation intervention be targeted in order to enhance organizational innovation capability? This paper suggests a procedure to locate the development targets of organizational innovation capability before making decisions on projects. Before the development of a measurement procedure, a more profound understanding of the phenomenon to be measured is needed. Thus, in light of the literature, an understanding of the concept of innovation capability in the context of practice-based innovation is accumulated. This paper will present a classification of the elements of innovation capability which provides a basis for the measurement instrument. Furthermore, we report on our practical experiences of implementing the procedure in a survey study in one organization.

\section{What is Innovation Capability in Practice-Based Innovation?}

Knowledge generation and learning in STI (Science-Technology-Innovation) (Jensen et al., 2007) is based on expert knowledge production and dissemination of codified knowledge. The science push effect as the driving force of innovations is an exception rather than a rule in innovation processes (Schienstock \& Hämäläinen, 2001). Rather, innovations seem to presume that companies possess the ability to interact, learn collectively, and build trusting relations between the innovating partners (Harmaakorpi, 2004). DUI (Doing-Using-Interacting) processes are informal processes of learning that entail experience-based know-how (Jensen et al., 2007). There is a tension between the STI and DUI modes which generates a need to pay attention not only to R\&D processes but also to learning from informal interaction and competence building with tacit elements (Jensen et al., 2007). In order to deeply understand the differences in innovative performance, there is a need to develop indicators that are DUI-based (Jensen et al., 2007). 
A significant body of innovation literature has its roots in the science-technology-innovation (STI) research stream (Jensen et al., 2007). In examining innovation capability from that viewpoint, it is usually seen as (R\&D) expenses spent on innovation generation as well as the amount of products or services or the revenue stream derived from these actions. Innovation processes are often studied as linear and analytical processes, including rational decision-making and problem solving (e.g. Tidd, Bessant, \& Pavitt, 2001).

The Doing-Using-Interacting (DUI) viewpoint examines the informal processes of learning and experience-based knowhow (Jensen et al., 2007). In the context of practice-based innovation in Mode $2 \mathrm{~b}$ knowledge generation on the organizational level, some aspects are examined more closely: developing innovation capability through breaking organizational silos, interpretative innovation processes, customers and employees as sources of innovations, tacit and symbolic knowledge, and organizational learning as a base for innovation capability (Harmaakorpi \& Melkas, 2012).

Table 1: Doing-Using-Interacting in practice-based innovation activities (An excerpt from Harmaakorpi \& Melkas, 2012)

\begin{tabular}{|c|c|c|}
\hline $\begin{array}{l}\text { Point of view; } \\
\text { Most typical... }\end{array}$ & $\begin{array}{l}\text { Practice-based innovation } \\
\text { (DUI, Mode 2a) }\end{array}$ & $\begin{array}{l}\text { Practice-based innovation } \\
\text { (DUI, Mode 2b) }\end{array}$ \\
\hline ... innovation types & $\begin{array}{l}\text { Radical concept innovations - } \\
\text { Technological system innovations }\end{array}$ & $\begin{array}{l}\text { Organizational innovations - social } \\
\text { innovations - service innovations }\end{array}$ \\
\hline ... fuels of innovation & Distance & "Near distance" \\
\hline ... logics & Related variety - innovation platforms & $\begin{array}{l}\text { Developing innovation capability - } \\
\text { breaking 'silos' and preventing bottle- } \\
\text { necks }\end{array}$ \\
\hline ... capital & Social capital - institutional capital & Social capital - structural capital \\
\hline ... innovation methods & Methods of intellectual cross-fertilisation & $\begin{array}{l}\text { Problem-based learning (e.g., culture- } \\
\text { based methods) }\end{array}$ \\
\hline ... origins of innovations & Networks - serendipity - customers & 'Normal' staff - customers \\
\hline ... types of knowledge & Self-transcending knowledge & Tacit knowledge \\
\hline ... knowledge transfer mechanisms & $\begin{array}{l}\text { Scanning and absorbing technology and } \\
\text { market signals }\end{array}$ & Organizational learning \\
\hline
\end{tabular}

Table 1 describes innovation and knowledge generation in Mode 2 practice-based innovation activities. Common to both Mode $2 \mathrm{a}$ and $2 \mathrm{~b}$ is interpretative innovation (Lester \& Piore, 2004) and brokerage as an ability to build possible worlds as a field of expertise (Harmaakorpi \& Melkas, 2012).

A rough division between Mode $2 \mathrm{a}$ and Mode $2 \mathrm{~b}$ is on the level of analysis; Mode 2a is more characteristic of inter-organizational innovation activities, whereas Mode $2 b$ is more common on the organizational level. In this paper the focus is more on the organizational level, i.e., on Mode 2 b. However, an organization is not an island; it is connected in many ways, for example, to its customers, partners, and suppliers. Therefore, we have to take both perspectives into consideration when thinking about practice-based innovation capability. Thus, the division is not blackand-white.

\section{Mode 2a Knowledge Generation and Innovation}

In the networked age, innovations are increasingly accomplishments of many people. Thus, fostering innovation means nurturing networks, exchanging ideas, and sharing knowledge not only within the organization but also outside of the organization. Innovation networks, such as links to 
customers, suppliers and technical institutes, are increasingly important to organizational innovation efforts.

The relations between actors in networks can be described as strong ties and weak ties. The strength of a tie is a combination of the amount of time, the emotional intensity, the intimacy and the reciprocal services that characterise the tie (Granovetter, 1973). Both strong and weak ties are important to innovation. Strong ties include a common language and a high level of trust, and weak ties enable the flow of new information to an organization. Weak ties allow for the diversity that is needed in innovations. Burt $(1992,2004)$ argues that innovations are most likely found in structural holes. Structural holes are often weak connections between clusters of densely connected individuals. Actors that are in the structural holes of two or more networks have a better chance of coming up with good ideas (Burt, 2004). A regional visionary capability is beneficial in functioning in multi-actor networks (Uotila, Melkas, \& Harmaakorpi, 2005).

In order to benefit from external knowledge in innovation activities, an organization needs to have proper acquisition and assimilation procedures. The term "absorptive capacity" means an organization's ability to value, assimilate, and apply new knowledge. Potential absorptive capacity enables the exploration of knowledge (often) over the weak ties, and realised absorptive capacity secures the exploitation (often) in the strong ties of the networks (W. Cohen \& Levinthal, 1990; Zahra \& George, 2002). Thus, the greater the internal capabilities of the firm, the greater are the effects of the different external knowledge acquisition strategies on innovation performance (Vega-Jurado, Gutierrez-Gracia, * Fernandez-de-Lucio, 2009). We will now turn to the internal capabilities of the firm.

\section{Mode 2b Knowledge Generation and Innovation}

One way to benefit from internal knowledge is to capitalize on the knowledge and ideas of current employees, including especially those who are not employed at the internal R\&D department. An employee's engagement in innovative work behaviours requires the employee to be both able and willing to be innovative. Amabile (1997) writes that expertise, creative thinking skills, and motivation, when mixed together, identify the level of creativity within an individual. The expertise component includes the memory for factual knowledge, technical proficiency, and special talents in the target domain. Creative thinking means that an individual is able to see things from more than one perspective and is able to question the existing working models. If problems are solved "the way they always have been solved," it blocks creativity and prevents new ideas from penetrating the organization. This requires that individuals can live with uncertainty (Shalley \& Gilson, 2004).

Organizational culture is considered crucial to an organization's ability to innovate (Van der Panne, Van der Beers, \& Kleinknech, 2003). The possession of positive cultural characteristics such as high autonomy, tolerance of mistakes, and continuous learning provides the organization with the necessary ingredients to innovate (Miron, Erez, \& Naveh, 2004). For example, workgroups tend to have a common, usually tacit understanding of how things work. These groups are called the subcultures of an organization (Schein, 1996). It is a challenging task to build communication and mutual understanding between different subcultures (Bechky, 2003; Schein, 1996).

A culture that favours playfulness enhances innovation capability. Styhre (2008) suggests that play contributes to the innovation research by highlighting factors such as serendipity and chance. Dodgson, Gann, and Salter (2005) use play to mediate the transfer from ideas to action by an exploration of the possible outcomes in the early stages of the innovation process. Anderson (1994) claims that play can be a significant motivator for employees.

Organic structures allow diversity and individual expression, and they are well suited to the initiation phase of innovation processes. They are also often more conducive to open and effective or- 
ganizational and interdepartmental communication. On the other hand, some level of stability, clarity, and coordination is needed. If formal mechanisms are absent, communication comes to depend solely on the discretionary and ad hoc effort of the organization members, which may not be sufficient (Parzefall, Seeck, \& Leppänen, 2008).

Creative work is ambiguous, risky, and subject to criticism. It can be expected that supportive supervision will facilitate creativity and innovation in the organization. For example, Oldham and Cummings (1996) found that support for creativity was related to innovation. Leaders may also influence creative work through the vision provided by charismatic or transformational leaders (Mumford, 2000). At the heart of transformational leadership is the notion that every employee has potential and a leader can help uncover the potential (Viitala, 2005).

Leadership that nourishes the renewal and motivation of the employees makes them aware of how important their work results are. It encourages employees to acquire new experiences and do more than is expected in their job description. In an ideal situation, leadership pushes employees to reach for higher needs and goals (Viitala, 2005; Yukl, 1998). Attending to people and managing their emotional connections is important for all kinds of organizational transformation. In order to manage the change successfully in the organization, the primary focus on leadership should be on managing the dynamics instead of on the individual parts of the organization (Duck, 1998).

\section{Categorization for Innovation Capability in Mode $2 b$ Practice- based Innovation}

Factors that support an employee's innovativeness are usually divided into four broad categories: individual, job, team, and organizational level (Shalley \& Gilson, 2004; Woodman, Sawyer, \& Griffin, 1993). Our division of practice-based innovation capability follows this logic. It is presented in Figure 1. As for organizational innovation capability, employees as individuals are the internal driving force for innovations. Tackling organizational silos opens the organization also inside and it is namely transformational leadership that enhances innovation capability. Absorptive capacity creates a link to externally (as well as internally) available sources of innovation.

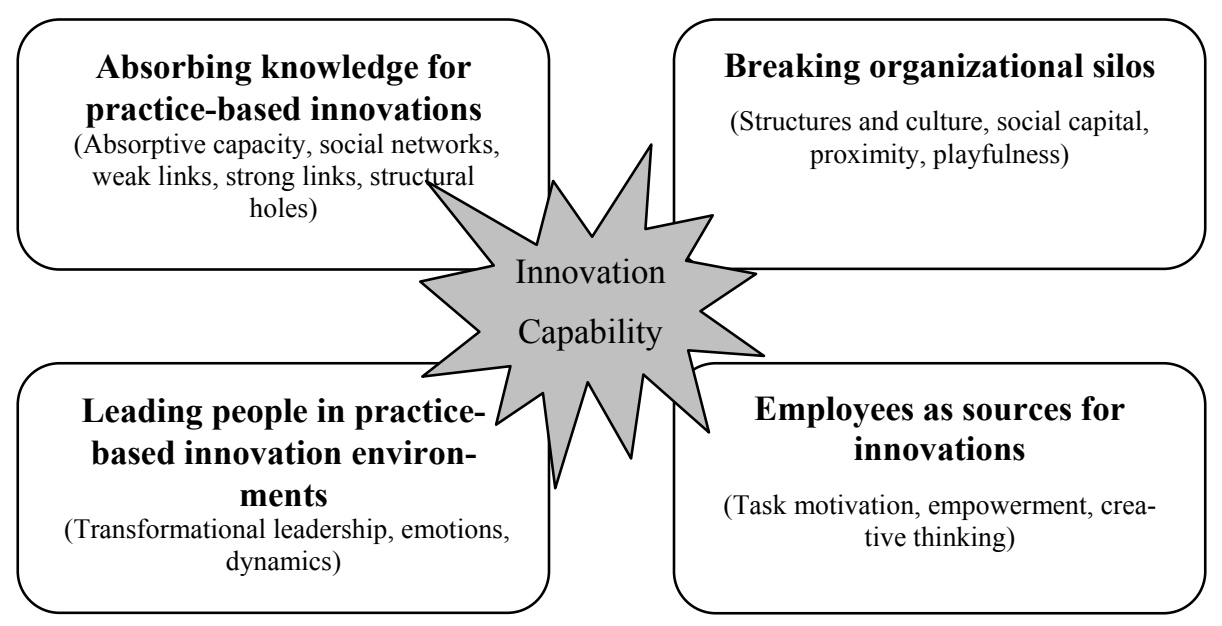

Figure 1: Elements of innovation capability

Figure 1 is a rough description of the factors that influence innovation capability. In organizations all these four elements are mixed, and probably the most effective combination is a mixture. This division, however, helps organizations to get a bigger picture of what is attached to innovation capability. 


\section{Measurement of Innovation Capability}

\section{Current Understanding}

Measurement can be used for different purposes in an organization. The basic function of measurement is to provide information about factors considered important. This information can be used for controlling that the targets are being reached and that the activities agreed upon are carried out as planned. Measures also act as "signals" highlighting the importance of the factor being measured and, thus, guide personnel in focusing their efforts. In addition, measurement can be used for learning. For example, reviewing measurement results and comparing them to previous results or results of another company/unit can provide an improved understanding of the development of the organization. Comparing the results with targets should, in the case of discrepancies, lead to asking questions such as "why has the target not been reached?" or "what new corrective actions can be implemented to improve the situation?" (Jääskeläinen, Kujansivu, \& Lönnqvist, 2009).

Measures can be divided into objective and subjective measures: objective measures are based on quantitative operational information, while subjective measures are based on the personnel's subjective assessments. Subjective measurement data is usually collected using survey questionnaires. On the other hand, measures can be classified as direct or indirect (Kemppilä \& Lönnqvist, 2003). When the phenomenon under examination cannot be measured directly (e.g., many intangible phenomena, such as the competence of employees), it can be approached indirectly. In such situations, surrogate factors (e.g., education) can be measured. What kind of measure is used should be decided specifically in each case. It is important to consider the benefits and burdens caused by the measurement when choosing the measure(s) for a specific phenomenon in a specific situation (Lönnqvist \& Mettänen, 2005).

In the literature, there are several models introduced for measuring certain components of innovation capability or related factors. For example,

1. Isaksen, Lauer, and Ekvall (1999)'s measurement procedure for a creative climate includes nine dimensions which are measured by using from three to seven items (answered on a four-point scale).

2. Prajogo and Ahmed (2006) introduced an instrument for innovation stimulus, innovation capacity, and innovation performance. The questionnaire includes eight elements, which comprise 34 questions. The questions are answered utilising a five-point Likert scale.

3. Kleysen and Street (2001) presented a revised measurement model for individual innovative behaviour. The model suggests 14 items to be measured using a six-point scale.

4. Kianto (2008) developed a model for an organization's renewal capability for continuous change. The model consists of six categories and the questionnaire is answered by the employees on a five-point Likert scale (strongly disagree - strongly agree).

The above-mentioned measurement models have some common features. They all use subjective evaluation to measure the phenomenon under examination. In addition, instead of trying to capture the phenomenon itself, they approach it indirectly by measuring surrogate factors. The approach is natural because gathering objective and direct measurement information of these phenomena is difficult or even impossible. Thus, subjective indirect measurement seems more appropriate also for our purposes.

The majority of the existing measurement models are based on STI-knowledge generation in innovation. However, Jensen et al. (2007) call for studies that use DUI-based indicators on innovation and learning. For example, in our measurement model we are not interested in patents, but rather in the interaction, i.e., whether people talk to people who have a different background. In 
the end, however, it should be recognized that measuring innovation needs both STI and DUI to some extent.

\section{Questionnaire for Evaluating Innovation Capability}

Our goal is not to measure the level of innovation capability but to locate the weak points that the organization currently has in innovation capability. Even though a questionnaire produces data that needs interpretation of its contextual factors, it seemed to be an appropriate procedure for our purposes. The aim was to develop a general procedure that is suitable for any kind of organizations and that takes into account the various elements of innovation capability (presented in Figure 1). In this study, designing a procedure can be characterised as researcher-driven, since the authors were responsible for creating the model. The questionnaire includes 15 statements (originally in Finnish) representing the four categories of innovation capability. The statements included in the questionnaire are presented in Table 2. The column 'Theses' explains how the authors see the statement as part of innovation capability. There was also a possibility for open answers after each category.

\section{Table 2: Statements (including references and theses)}

\begin{tabular}{|c|c|c|c|}
\hline & Statement & References & Theses \\
\hline \multirow[t]{4}{*}{$\begin{array}{l}\text { Absorbing } \\
\text { knowledge }\end{array}$} & $\begin{array}{l}\text { I use time to make and nur- } \\
\text { ture connections outside the } \\
\text { organization }\end{array}$ & $\begin{array}{l}\text { Burt, 2004; Granovetter, } \\
1973\end{array}$ & $\begin{array}{l}\text { Not all connections are } \\
\text { useful today }\end{array}$ \\
\hline & $\begin{array}{l}\text { I get ideas from our associ- } \\
\text { ates }\end{array}$ & $\begin{array}{l}\text { Hargadon, 1998; Todorova \& } \\
\text { Durisin, } 2007\end{array}$ & $\begin{array}{l}\text { To acquire ideas is one } \\
\text { thing, to recognise the po- } \\
\text { tential is another }\end{array}$ \\
\hline & $\begin{array}{l}\text { We collect systematically } \\
\text { customer feedback }\end{array}$ & $\begin{array}{l}\text { Griffin \& Hauser, 1993; Von } \\
\text { Hippel, } 1988\end{array}$ & $\begin{array}{l}\text { A systematic channel is } \\
\text { ensured }\end{array}$ \\
\hline & $\begin{array}{l}\text { We generate ideas for new } \\
\text { products and/or services with } \\
\text { customers }\end{array}$ & $\begin{array}{l}\text { Sawhney \& Pradelli, 2000; } \\
\text { Von Hippel, } 2005\end{array}$ & $\begin{array}{l}\text { The customer's role is } \\
\text { changing from object to } \\
\text { subject }\end{array}$ \\
\hline \multirow[t]{4}{*}{$\begin{array}{l}\text { Breaking } \\
\text { organiza- } \\
\text { tional silos }\end{array}$} & $\begin{array}{l}\text { Cooperation between differ- } \\
\text { ent functions works well }\end{array}$ & $\begin{array}{l}\text { Brown \& Eisenhard, 1995; } \\
\text { Kallio \& Bergenholtz, 2011; } \\
\text { Moorman \& Miner, } 1998\end{array}$ & $\begin{array}{l}\text { Innovation potential lies in } \\
\text { the interfaces of different } \\
\text { fields of expertise }\end{array}$ \\
\hline & We learn from mistakes & Miron, Erez, \& Naveh, 2004; & $\begin{array}{l}\text { Mistakes are important- as } \\
\text { long as lessons are learned } \\
\text { from those }\end{array}$ \\
\hline & $\begin{array}{l}\text { My nearest working envi- } \\
\text { ronment is playful }\end{array}$ & $\begin{array}{l}\text { Anderson, 1994; Dodgson, } \\
\text { Gann, \& Salter, 2005; Styhre, } \\
\text { 2008; }\end{array}$ & $\begin{array}{l}\text { "Play energizes us" (quote } \\
\text { from Andersson 1994) }\end{array}$ \\
\hline & $\begin{array}{l}\text { Meetings are discursive and } \\
\text { open }\end{array}$ & $\begin{array}{l}\text { Bechky, 2003; Huber \& } \\
\text { Lewis, 2010; Schein, } 1996\end{array}$ & $\begin{array}{l}\text { Very often organizations } \\
\text { suffer from a communica- } \\
\text { tion gap that prevents inno- } \\
\text { vation and creativity }\end{array}$ \\
\hline \multirow[t]{3}{*}{$\begin{array}{l}\text { Leading } \\
\text { people }\end{array}$} & $\begin{array}{l}\text { My supervisor encourages } \\
\text { me to express my opinion on } \\
\text { things }\end{array}$ & $\begin{array}{l}\text { Bass, 1985; DiLielleo \& } \\
\text { Houghton, 2006; Viitala, } \\
\text { 2005; Yuk1, 1998 }\end{array}$ & $\begin{array}{l}\text { The leader does not have all } \\
\text { the knowledge, but is sup- } \\
\text { ported by the professionals }\end{array}$ \\
\hline & $\begin{array}{l}\text { I am contributing to the } \\
\text { future of our organization }\end{array}$ & $\begin{array}{l}\text { DiLielleo \& Houghton, 2006; } \\
\text { Jung, Chow, \& Wu, } 2003\end{array}$ & $\begin{array}{l}\text { By taking the employees } \\
\text { along to design strategy, } \\
\text { there is no need to translate } \\
\text { and diffuse it to the person- } \\
\text { nel }\end{array}$ \\
\hline & $\begin{array}{l}\text { I can try out new things, even } \\
\text { if they weren't part of my } \\
\text { duties }\end{array}$ & $\begin{array}{l}\text { Gumusluoglu and Ilsev, } \\
\text { 2009; Viitala, } 2005\end{array}$ & $\begin{array}{l}\text { You see the storm better if } \\
\text { you don't stand in the eye of } \\
\text { it }\end{array}$ \\
\hline
\end{tabular}




\begin{tabular}{llll}
\cline { 2 - 4 } & $\begin{array}{l}\text { My supervisor makes effort } \\
\text { to make things happen }\end{array}$ & $\begin{array}{l}\text { Hyypiä \& Parjanen 2008; } \\
\text { Yukl, 1998 }\end{array}$ & $\begin{array}{l}\text { If the leader makes all the } \\
\text { effort, I want to do my best } \\
\text { as well }\end{array}$ \\
\hline $\begin{array}{l}\text { Employees as } \\
\begin{array}{l}\text { sources for } \\
\text { innovation }\end{array}\end{array}$ & \begin{tabular}{l} 
I tolerate uncertainty well \\
\cline { 2 - 4 }
\end{tabular} & $\begin{array}{l}\text { Lester \& Piore, 2004; Shalley } \\
\text { \& Gilson, 2004 }\end{array}$ & $\begin{array}{l}\text { An open-ended process } \\
\text { leaves room for serendipi- } \\
\text { tous events }\end{array}$ \\
\cline { 2 - 4 } & $\begin{array}{l}\text { I participate in the organiza- } \\
\text { tion's innovation activities }\end{array}$ & Axtell et al., 2000 & $\begin{array}{l}\text { The employee is the best } \\
\text { developer of his/her own } \\
\text { work }\end{array}$ \\
\cline { 2 - 4 } & I am good at generating ideas & $\begin{array}{l}\text { Amabile, 1997; Bandura, } \\
1993 ; \text { Morrison \& Phelps, } \\
1999\end{array}$ & Self-efficacy \\
\hline
\end{tabular}

The 15 statements presented were chosen among 55 initial statements during a process that involved other researchers as well in the field of practice-based innovation. First, a small group of people gathered to list themes. Then a brief literature review was written and it was sent out to researchers for comments and additions. Then statements were formed according to the literature review on practice-based innovation as well as earlier research available on measuring innovation capability. Then a workshop was held with a few researchers where the questionnaire was reworked again and sent out for a final comment round.

The survey was carried out at the employee level. The responses were gathered from those people that are (or should be) affected by the possibly following intervention. This gives the developers information of the actual practitioners' opinions. Overall, the survey provides an understanding of the innovation capability of the organization at current time. After carrying out the survey and analysing the data, the weak points of innovation capability were revealed.

All groups of statements are equal regarding innovation capability and should, thus, be in balance; it is not enough to reinforce leadership if the structures are not flexible. Nor is it meaningful to absorb external knowledge if the organization is incapable of turning it into something useful. The statements, however, cannot be held equal as they are dependent on the context. The interpretation of the results matters the most.

\section{Implementing the Model}

\section{Case Context}

The case organization is a part of a bigger group providing services for the supermarket trade, the service station store and fuel trade, the department store and speciality store trade, the tourism and hospitality business, the automotive and accessories trade, as well as the agricultural trade. The case organization is a department store for products related to living. Its main product areas are plants and the garden and interior decorating, renovating, and building. From the case organization, a customer can get interior decorating equipment and tools as well as house packages. In addition, there are also store-specific services such as garden design and interior decorating design available. There are 55 employees in the case organization.

\section{Data and Analysis Methods}

A survey was conducted in September 2009. In practice, an invitation to participate in the study was sent via email. The survey was carried out at the level of individual workers. In total, 39 responses are included in the study. The background information of the respondents is presented in Table 3. 
Table 3: Background information of the respondents

\begin{tabular}{llrr}
\hline & & $n$ & $\%$ \\
\hline Age & Under 20 years & 2 & 5.1 \\
& $20-30$ years & 23 & 59.0 \\
& $31-40$ & 7 & 17.9 \\
& $41-50$ & 4 & 10.3 \\
\multirow{3}{*}{ Gender } & $51-60$ & 3 & 7.7 \\
& Male & 15 & 38.5 \\
\multirow{3}{*}{ Working years in the organization } & Female & 24 & 61.5 \\
& Under 2 years & 6 & 15.4 \\
& 2-5 years & 25 & 64.1 \\
& 6-10 years & 5 & 12.8 \\
& Over 10 years & 3 & 7.7 \\
\hline
\end{tabular}

We used ZEF software in gathering the responses and analysing the data. ZEF software allows answering by using a continuous scale (0-100 \%) in two dimensions. So being, answering the questionnaire is visual and answers can be put into a visual diagram. We had "is important" on the x-axis and "currently happening" on the y-axis. Since the statements were subjective, it can be assumed that even though people would have thought about the answers from the company's point of view, their personal interests affected their answers.

Later, responses related to each statement were classified into four groups according to their importance and whether they are happening currently. The groups are the following: "not important and does not happen currently"; "not important but happens currently"; "important but does not happen currently"; and "important and happens currently". Issues that are considered important but are not happening currently are the ones that should be prioritized in development. If people feel the focus of a development project is important, they will more likely be engaged with it. On the other hand, issues that are happening a lot but are not considered important consume resources ineffectually, since people will participate in the project only because they have to but they do not think the focus is important. In conclusion, it is not that the other weak points would not be worth focusing on, it is just better to start with those that people can be engaged with to make the changes happen by themselves.

\section{Results and Analysis}

The data is first examined by using the means of the responses related to the 15 statements. Twelve of the statements were assessed from the point of view of their importance and whether the issue in question is currently happening within the organization. The last three statements were only assessed from the perspective of "importance." This can be considered a weakness for the scientific testing of the model, but in practice in the case at hand, it was seen as a proper way at the current time. In designing surveys, it is good to make them as easy as possible to answer. As the emphasis was on the organizational innovation development projects, it was not seen as essential to collect personal-level self-reflective data. In communicating the results and implementing development projects, this data was actualised only on a normative level. The means are presented in Table 4. 
Table 4: The means of responses related to different statements

\begin{tabular}{|c|c|c|}
\hline Statement & $\begin{array}{r}\text { Importance } \\
(\text { mean }) \\
\end{array}$ & $\begin{array}{r}\text { Currently happening } \\
\text { (mean) }\end{array}$ \\
\hline $\begin{array}{l}\text { I use time to make and nurture connections outside the organiza- } \\
\text { tion }\end{array}$ & 39,8 & 40,0 \\
\hline I get ideas from our associates & 54,2 & 54,9 \\
\hline We collect customer feedback systematically & 63,6 & 62,1 \\
\hline $\begin{array}{l}\text { We generate ideas for new products and/or services with cus- } \\
\text { tomers }\end{array}$ & 44,2 & 33,3 \\
\hline Cooperation between different functions works well & 52,1 & 38,6 \\
\hline We learn from mistakes & 70,4 & 63,4 \\
\hline My nearest working environment is playful & 58,9 & 53,1 \\
\hline Meetings are discursive and open & 61,3 & 54,4 \\
\hline My supervisor encourages me to express my opinion on things & 59,8 & 63,7 \\
\hline I am contributing to the future of our organization & 51,3 & 49,3 \\
\hline I can try out new things, even if they weren't part of my duties & 65,4 & 71,0 \\
\hline My supervisor makes effort to make things happen & 65,3 & 64,7 \\
\hline I tolerate uncertainty well & 30,9 & \\
\hline I participate in the organization's innovation activities & 61,6 & \\
\hline I am good at generating ideas & 65,6 & \\
\hline
\end{tabular}

Learning from mistakes (mean 70.4) was considered the most important issue. It is followed by other important aspects: generating ideas (65.6), trying out new things (65.4), effective supervisor (65.3), collecting customer feedback systematically (63.6) and discursive and open meetings (61.3). The least important matters were tolerating uncertainty (30.9) and making connections (39.8). It was surprising that tolerating uncertainty was so low, because earlier the organization was able to operate relatively freely and could decide many things locally. Now there are more department stores under the same concept and there is confusion about what things can be decided locally. With respect to innovation capability, the low figure of tolerating uncertainty and making connections is interesting. Tolerance of uncertainty has links to the cross-boundaries cooperation. It can be interpreted that the innovation process in the organization is analytical. In a well-defined project world, there is no slack or room for serendipity. In an interpretative innovation process (Lester \& Piore, 2004), the end result is not foreseen in the beginning. It requires the ability to believe in serendipity and to be able to live in that uncertainty. It also requires faith that the right answers will be revealed in the course of action.

Issues that are considered to be currently happening are trying out new things (71.8), effective supervisor (64.7), encouraging supervisor (63.7), learning from mistakes (63.4) and systematically collecting customer feedback (62.1). On the other hand, the results show that generating ideas (33.3) and co-operation between different functions (38.6) are the ones that are not happening that much.

Figure 2 presents the percentage of the responses in the various groups regarding the four statements on absorbing knowledge. According to the results, one of the challenges seems to be generating ideas with customers. $25 \%$ of the respondents felt that it is an important issue but not happening. Another important matter, but which is not that much carried out, is collecting customer feedback (around $23 \%$ ). However, around $18 \%$ of the respondents did not think that it is an important issue, but the company is doing it. This could be a signal of using one-way and inappropriate ways to collect customer knowledge. In fact, some of the employees do not even recognize that customer feedback was collected in the first place. Thus, we recommend that the company should adopt dialogical manners to interact with customers. 


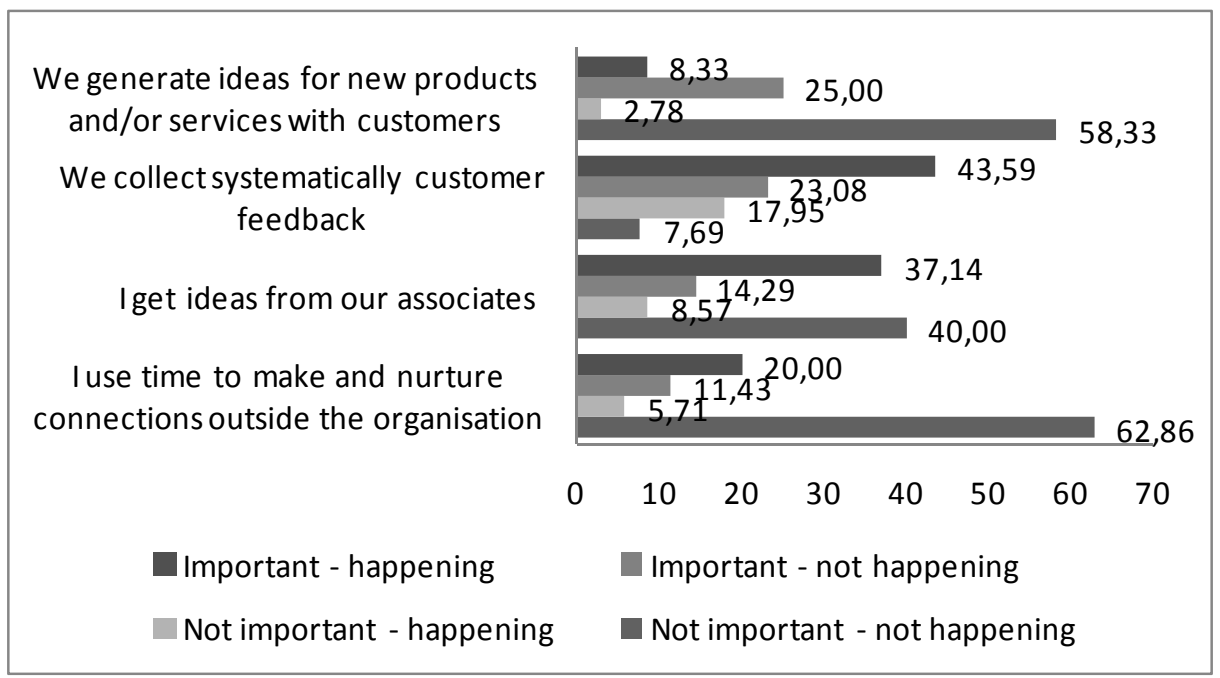

Figure 2: Absorbing knowledge

From the perspective of breaking organizational silos (see Figure 3), the most significant development target is co-operation between different functions. Around $37 \%$ of the respondents consider it an important issue, but it is not happening currently. The results show that the other three factors were also regarded as important but not actualised in practice, according to $23-27 \%$ of the respondents. Even though a first hands-on development project to be considered would be cooperation between different functions, other statements need attention as well. As it is now, we suggest cultural tools, for example organizational theatre (Pässilä \& Oikarinen, in press; Pässilä, Oikarinen, \& Vince, 2012) to be used in this case. If the other statements were to be considered more important, a more analytical and traditional tool could be used.

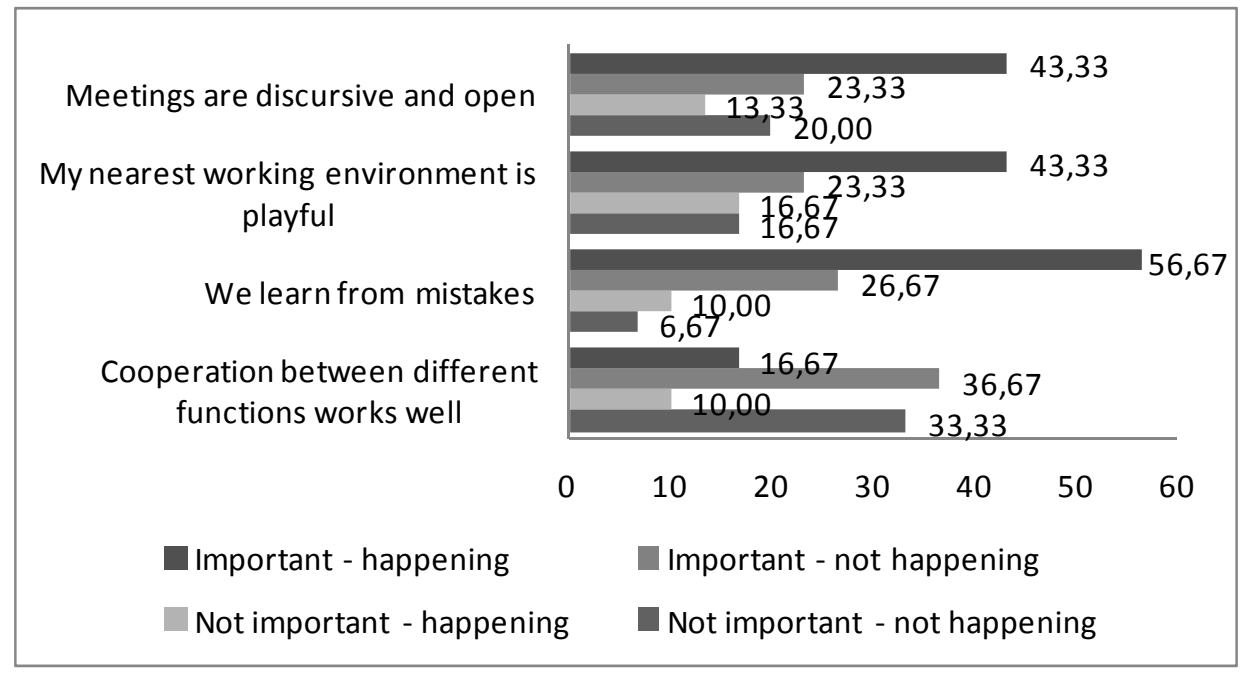

Figure 3: Breaking organizational silos

The results related to leading people statements are provided in Figure 4. According to $25 \%$ of the respondents, contributing to the organization's future is an important matter but not very 
much actualised in practice. The results show that around $28 \%$ consider trying out new things not that important an issue, but it is happening in practice.

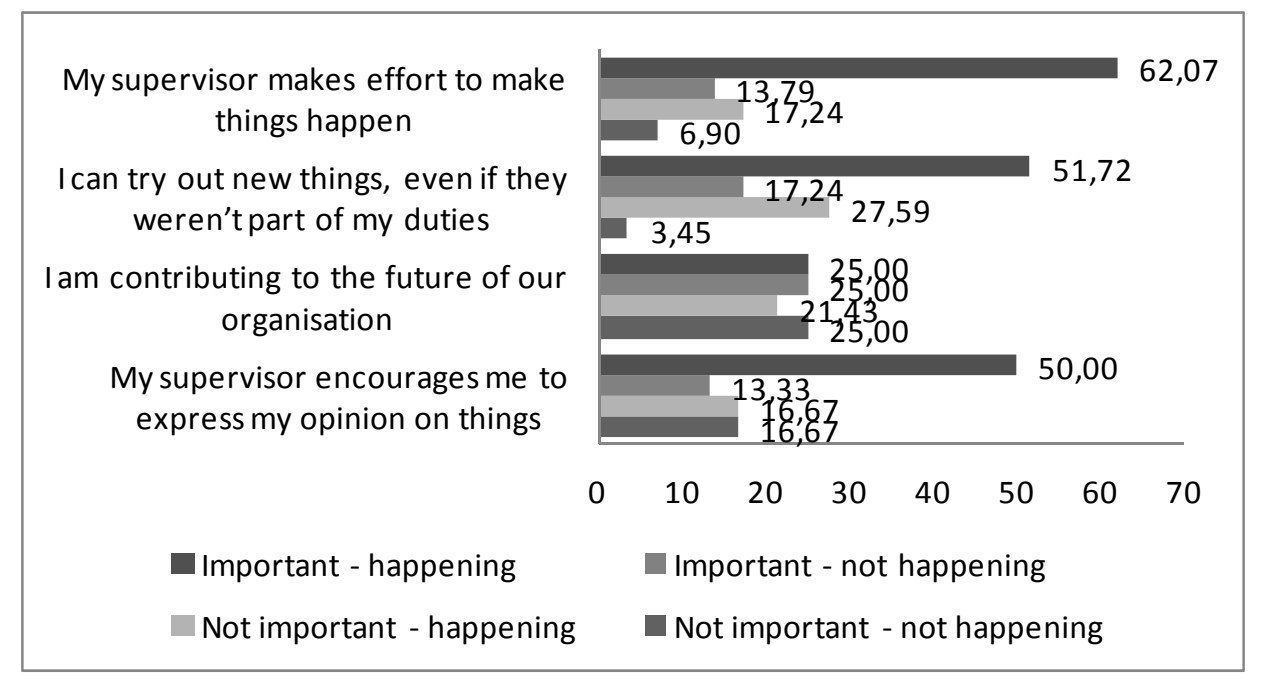

Figure 4: Leading people

\section{Summary of Survey Results and Suggestions for Development Work}

It is assumed that the factors of innovation capability considered important but which do not happen currently are the ones that should be paid attention to in the first place. People are most likely to make an effort for these kinds of development projects. If they do not see the development target as important, they will participate in the project only because they are forced, not because they want to make a difference.

The majority of the respondents thought that "We generate ideas for new products and/or services with customers" is not happening. In addition, most respondents did not see this as important, whereas one fourth considered it important (but not happening). It can be interpreted that a customer is seen as an object of innovation activities that happen inside the organization. In order to leverage their innovation capability, the employees could enhance the two-way dialogue by upgrading the customer to be a subject of innovation activities.

"Cooperation between different functions works well" was definitely not happening according to the respondents. Moreover, around half of them considered it important and a half did not. This is clearly a fruitful, yet difficult, development area. Often the greatest innovation potential lies in the interfaces between different focus groups. The boosting of communication between different units could increase the amount of "lucky coincidences" in innovative ideas. However, the creation of multi-actor dialogue is not an easy process and it should be provided with enough time and delicacy.

"We learn from mistakes" is interesting. It is clearly seen as important and the majority of the respondents think that it is happening at the moment. However, a significant amount of the respondents feel that it is not happening. This could be a start of a fruitful discussion - how do the employees perceive that they are / are not learning from mistakes?

In general, the respondents were pleased with the leadership in the organization. They thought that it is easy to talk to the supervisor and that the supervisors are putting themselves on the line as well. All the issues presented in the statements were seen as important and going well, except for one: "I am contributing to the future of our organization". Half of the respondents think it is 
important, but only $25 \%$ think it is happening. What is alerting is that $25 \%$ of the respondents think that it is neither important nor happening.

Those statements that the respondents see as important but which are not currently happening are the kinds of development areas that are recognised. However, there are areas that the respondents did not see as important for them. The development interventions should be targeted first to the areas that the employees already feel that are important. In the meantime, the general level of consciousness of innovation capabilities can be increased, and the employees may be more willing to engage in other development areas later. For example, over $60 \%$ of the respondents think that "I use time to make and nurture connections outside the organization" is neither happening nor important. In the long run, this kind of thinking leads to a situation where no new ideas are absorbed into the organization. Examples of possible actions towards excellence in organizational innovation capability are:

1. Breaking organizational silos: Practices to boost the communication between different functions; this is suggested to be done with cultural tools such as organizational theatre (For organizational theatre, see Pässilä \& Oikarinen, in press)

2. Absorbing knowledge: Customer to be subject of innovation activities; this is suggested to be done with dialogical methods that entail two-way communication, not just a questionnaire to the customers

3. Leading people: Personnel brought along to design the next strategy

At this point we know which areas need development the most. In order to increase innovation capability, it is necessary to increase cooperation between different functions and to take the customer to be an active subject of innovation activities. One point further, the organization could take the employees along to design the next strategy. Employees consider it rather important that everyone takes part in the organization's innovation activities. When it comes to the individual tolerance of uncertainty, the case is not the same. It should not be taken as a strict requirement for everyone to be comfortable with uncertainty. However, if the organization seeks interpretative innovation (Lester \& Piore, 2004), employees should acknowledge that the uncertainty is an important part of it.

The suggestions described here are not something a company can conduct in a quarter of a year. In fact, organizational change emerges from cultural rethinking. Change most probably takes years and requires resources and long-distance planning. The choice of tools depends on the available resources. However, employees should be taken along to design the change.

\section{Discussion}

With the help of a single case study, this study sheds light on the practical question of how an innovation intervention should be targeted in order to enhance organizational innovation capability. This study contributes to developing measures for DUI environments (see Jensen et al., 2007). Building on the work of Harmaakorpi and Melkas (2012), this study further develops measures for the division in DUI Mode $2 \mathrm{a}$ and DUI Mode $2 \mathrm{~b}$ knowledge generation and learning.

This paper makes a contribution to the existing research on innovation management by increasing the understanding of the concept of innovation capability (e.g. Koivisto, 2005) in the context of practice-based innovation activities (Ellström, 2010; Melkas \& Harmaakorpi, 2012). More specifically, it provides a theoretical categorization for the elements of innovation capability in this context.

The results of this paper may be considered valuable also from the managerial point of view. Managers recognise the importance of innovation capability for the success of the organization. However, the decisions on what should be developed specifically are often based on intuition. 
The questionnaire created to measure innovation capability is used not only to assess the status of innovation capability with the help of bottom-up knowledge of the current state of affairs but also as a diagnosis method for facilitating the decision making of managers as to where to target the development projects.

In analysing the results, it is important to bear in mind that even though something might stand out as a problematic area for innovation capability, possibly years of work may be needed before it is possible to tackle that spot directly. It should also be discussed whether actions aiming at changing one thing will have an effect on the other areas of interest. For example, the uncertainties will probably increase when starting communication between different functions that have different interests. Another thing is, will the tolerance of uncertainty actually increase?

As limitations of our measurement instrument, some points can be recognised. First, the amount of data used in this paper is quite small. Our purpose was to design a questionnaire and to test it in a single case organization in order to find weak points related to innovation capability. For this purpose, the data can be considered representative (39 out of 55 employees responded). However, from the point of view of developing the measurement instrument further, a larger sample is needed. To be able to validate the measurement method, additional case studies need to be carried out. The measurement model should be examined as a whole, i.e., two dimensions should be used with all statements. Furthermore, a factor analysis could be carried out in order to find out whether the questionnaire includes sound elements. The third limitation of the questionnaire is that it does not say anything about the actual outputs or outcomes. The questionnaire should be repeated after the development project. In this way, it is possible to evaluate the effects that the actions have had. However, it should be noted that in addition to a specific intervention, other changes may also occur (changes in the economic situation and other development work carried out in a similar manner). Thus, it can be difficult to determine which of the acquired benefits are caused by the development initiative in particular and which result from other factors. On the other hand, it may take some time before the impact of a development project is realised. Thus, the outcomes may not have been realised at the time of assessment.

\section{Acknowledgements}

The authors wish to thank the anonymous reviewers for their feedback and comments. The authors also want to thank the whole personnel of Lahti School of Innovation at Lappeenranta University of Technology for taking part in developing the survey questions. The authors wish to thank the European Regional Development Fund and the Regional Council of Päijät-Häme for the possibility to conduct and publish their research.

\section{References}

Amabile, T. (1997). Motivating creativity in organizations: On doing what you love and loving what you do. California Management Review, 40(1), 39-58.

Anderson, J. V. (1994). Creativity and play: A systematic approach to managing innovation. Business Horizons, March-April, 80-85.

Axtell, C., Holman, D., Unsworth, K., Will, T., Waterson, P., \& Harrington, E. (2000). Shopfloor innovation: Facilitating the suggestion and implementation of ideas. Journal of Occupational and Organizational Psychology, 39, 599-617.

Bandura, A. (1993). Perceived self-efficacy in cognitive development and functioning. Educational Psychologist, 28(2), 117-148.

Bass, B. (1990). Handbook of leadership: A survey of theory and research. New York: Free Press. 
Bechky, B. (2003). Sharing meaning across occupational communities: The transformation of understanding on a production floor. Organization Science, 14(3), 312-330.

Brown, S., \& Eisenhardt, K. (1995). Product development: past research, present findings, and future directions. Academy of Management Review, 20(2), 343-78.

Burt, R. (1992). Structural holes: The social structure of competition. Boston: Harvard University Press.

Burt, R. (2004). Structural holes and good ideas. American Journal of Sociology, 110(2), 349-399.

Cohen, M., March, J., \& Olsen, J. (1972). A garbage can model of organizational choice. Administrative Science Quarterly, 17(1), 1-25.

Cohen, W., \& Levinthal, D. (1990). Absorptive capacity: A new perspective on learning and innovation. Administrative Science Quarterly, 35, 128-152.

DiLielleo, T., \& Houghton, J. (2006). Maximizing organizational leadership capacity for the future: Toward a model of self leadership, innovation and creativity. Journal of Managerial Psychology, 21, $319-37$.

Dodgson, M., Gann, D., \& Salter, A. (2005). Think, play, do: Technology, innovation, and organization. Oxford: Oxford University Press.

Duck, J. D. (1998). Managing change: The art of balancing. Boston: Harvard Business Review.

Ellström, P-E. (2010). Practice-based innovation: A learning perspective. Journal of Workplace Learning, $22(1 / 2), 27-40$

Granovetter, M. (1973). The strength of weak ties. American Journal of Sociology, 78, 1360-1380.

Griffin, A., \& Hauser, J.R. (1993). The voice of the customer. Marketing Science, 12(1), 1-27.

Gumusluoglu, L., \& Ilsev, A. (2009). Transformational leadership, creativity, and organizational innovation. Journal of Business Research, 62, 461-473.

Hargadon, A. B. (1998). Knowledge brokers: A field study of organizational learning and innovation. Academy of Management Proceedings: San Diego, CA.

Harmaakorpi, V. (2004). Building competitive regional innovation environment - The regional development platform method as a tool for regional innovation policy. Helsinki University of Technology, Department of Industrial Engineering and Management.

Harmaakorpi, V., \& Melkas, H. (2012). Epilogue. In Melkas, H., \& Harmaakorpi, V. (Eds.) Practice-based innovation: Insights, applications and policy implications (pp. 437-452). Heidelberg: Springer.

Huber, G., \& Lewis, K. (2010). Cross-understanding: Implications for group cognition and performance. Academy of Management Journal, 35(1), 6-26.

Hyypiä, M., \& Parjanen, S. (2008). Boosting the creativity and communication in innovation processes Preliminary results from the qualitative study. In the Proceedings of the $5^{\text {th }}$ International Conference on Intellectual Capital, Knowledge Management \& Organisational Learning, New York Institute of Technology, New York, USA, 9-10 October 2008.

Isaksen, S., Lauer, K., \& Ekvall, G. (1999). Situational outlook questionnaire: A measure of the climate for creativity and change. Psychological reports, 85, 665-674.

Jensen, M., Johnson, B., Lorenz, E., \& Lundvall, B-A. (2007). Forms of knowledge and modes of innovation. Research Policy, 36(5), 680-693.

Jääskeläinen, A., Kujansivu, P., \& Lönnqvist, A. (2009). Learning from existing performance information in public service organizations. Paper presented at the 5th Conference on Performance Measurement and Management Control. September 23-25, 2009. Nice, France.

Jung, D. I., Chow, C., \& Wu, A. (2003). The role of transformational leadership in enhancing organizational innovation: Hypotheses and some preliminary findings. The Leadership Quarterly, 14, 525-544. 
Kallio, A., \& Bergenholtz, C. (2011). Generating innovation opportunities - Exploring and absorbing customer knowledge. International Journal of Technology Management, 56(2/3/4), 172-187.

Kemppilä, S., \& Lönnqvist, A. (2003). Subjective productivity measurement. The Journal of American Academy of Business, Cambridge, 2(2), 531-537.

Khurana, A., \& Rosenthal, S. R. (1997). Integrating the fuzzy front end of new product development. Sloan Management Review, 38(2), 103-120.

Kianto, A. (2008). Development and validation of a survey instrument for measuring organisational renewal capability. International Journal of Technology Management, 42(1/2), 69-88.

Kleysen, R., \& Street, C. (2001). Toward a multi-dimensional measure of individual innovative behavior. Journal of Intellectual Capital, 2(3), 284-296.

Koivisto, T. (2005) Developing strategic innovation capability of enterprises - Theoretical and methodological outlines of intervention. VTT Publications 586.

Lester, R., \& Piore, M. (2004). Innovation the missing dimension. London: Harvard University Press.

Lönnqvist, A., \& Mettänen, P. (2005). Criteria of sound intellectual capital measures. In S. Kambhammettu (Ed.), Business performance measurement: Towards functional excellence (pp. 97-120). India: Le Magnus University Press.

Melkas, H., \& Harmaakorpi, V. (2012). Introduction. In Melkas, H., \& Harmaakorpi, V. (Eds.) Practicebased innovation: Insights, applications and policy implications (pp. 1-13). Heidelberg: Springer.

Miron, E., Erez, M., \& Naveh, E. (2004). Do personal characteristics and cultural values that promote innovation, quality, and efficiency compete or complement each other? Journal of Organizational Behavior, 25(2), 175-199.

Moorman, C., \& Miner, A. (1998). Organizational improvisation and organizational memory. Academy of Management Review, 23(4), 698-723.

Morrison, E. W., \& Phelps, C. (1999). Taking charge at work: Extra-role efforts to initiate workplace change. Academy of Management Journal, 42, 403-419.

Mumford, M. (2000). Managing creative people: Strategies and tactics for innovation. Human Resource Management Review, 10(3), 313-351.

Oldham, G., \& Cummings, A. (1996). Employee creativity: Personal and contextual factors at work. The Academy of Management Journal, 39(3), 607-634.

Parjanen, S., Harmaakorpi, V., \& Frantsi, T. (2010). Collective creativity and brokerage functions in heavily cross-disciplined innovation processes. Interdisciplinary Journal of Information, Knowledge and Management, 5, 1-21. Retrieved from http://www.ijikm.org/Volume5/IJIKMv5p001021Parjanen433.pdf

Parzefall, M-R, Seeck, H., \& Leppänen, A. (2008). Employee innovativeness in organizations: A review on the antecedents. Finnish Journal of Business Economics, 2, 165-182.

Prajogo, D., \& Ahmed, P. (2006). Relationships between innovation stimulus, innovation capacity, and innovation performance. $R \& D$ Management, 36(5), 499-515.

Pässilä, A., \& Oikarinen, T. (in press). Research-based theatre as a facilitator for organisational learning. P. Meusburger, A. Berthoin, \& M. Ries (Eds.), Learning organizations: The importance of place for organizational learning. Dordrecht: Springer Verlag.

Pässilä, A., Oikarinen, T., \& Vince, R. (2012). The role of reflection, reflection on roles: Practice-based innovation through theatre-based learning. In H. Melkas \& V. Harmaakorpi (Eds.), Practice-based innovation: Insights, applications and policy implications (pp. 173-191). Heidelberg: Springer.

Sawhney, M., \& Pradelli, E. (2000). Beyond customer knowledge management: Customers as knowledge co-creators. In Y. Malhotra (Ed.), Knowledge management and virtual organizations (pp. 258-281). UK: Idea Group Publishing. 
Schein, E. (1996). Three cultures of management: The key to organizational learning. Sloan Management Review, 38(1), 9-20.

Schienstock, G., \& Hämäläinen, T. (2001). Transformation of the Finnish innovation system: A network approach. Helsinki: Sitra.

Shalley, C., \& Gilson, L. (2004). What leaders need to know: A review of social and contextual factors that can foster or hinder creativity. Leadership Quarterly, 15(1), 33-53.

Styhre, A. (2008). The play of innovation: New drug development and Roger Caillois's theory of play. Creativity and Innovation Management, 17(2), 136-146.

Tatikonda, M., \& Rosenthal, S. (2000). Successful execution of product development projects: Balancing firmness and flexibility in the innovation process. Journal of Operations Management, 18, 401-425.

Tidd, J., Bessant, J., \& Pavitt, K. (2001). Managing innovation. Integrating technological, market and organizational change. UK: Wiley \&Sons.

Todorova, G., \& Durisin, B. (2007). Absorptive capacity: Valuing a reconceptualization. Academy of Management Review, 32(3), 774-786.

Uotila, T., Melkas, H., \& Harmaakorpi, V. (2005). Incorporating futures research into regional knowledge creation and management. Futures, 37, 849-866.

Van der Panne, G., van der Beers, C., \& Kleinknecht, A. (2003). Success and failure of innovation: A literature review. International Journal of Innovation Management, 7(3), 309-339.

Vega-Jurado, J., Gutierrez-Gracia, A., \& Fernandez-de-Lucio, I. (2009). Industrial and Corporate Change, $18(4), 637-670$.

Viitala, R. (2005). Johda osaamista! Keuruu: Otavan Kirjapaino Oy.

Von Hippel, E. (1988). The sources of innovation. New York: Oxford University Press.

Von Hippel, E. (2005). Democratizing innovation. Cambridge Massachusetts: The MIT Press.

Woodman, R. W., Sawyer, J. E., \& Griffin, R. W. (1993). Toward a theory of organizational creativity. Academy of Management Review, 18(2), 293-321.

Yukl, G. (1998). Leadership in organizations. New Jersey: Prentice Hall.

Zahra S., \& George, G. (2002). Absorptive capacity: A review, reconceptualization and extension. Academy of Management Review, 27(2), 185-203. 


\section{Biographies}

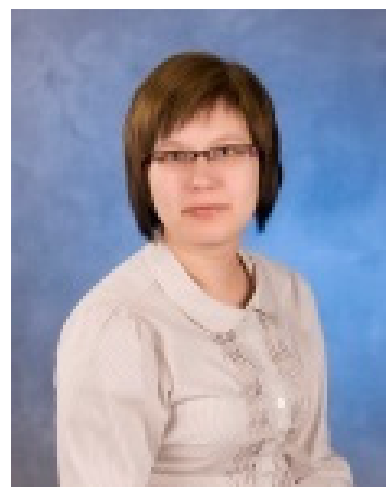

Anne Kallio, M.Sc. (Econ. \& Bus. Adm.) is a researcher at LUT Lahti School of Innovation, Finland. Her PhD studies focus on revealing the innovation potential hiding in everyday activities of organizations. She has conducted several action research processes in different organizations. Anne Kallio's research interests are absorptive capacity, social capital and shopfloor employees' role in innovation. She has previously published in Urban Studies and International Journal of Technology Management.

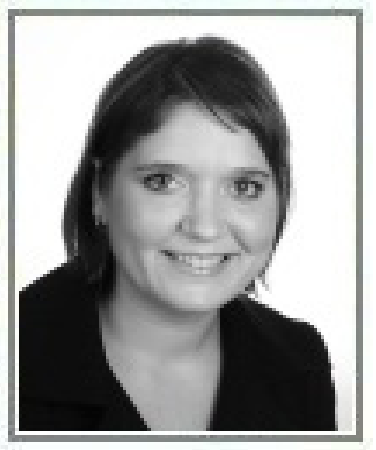

Paula Kujansivu (Dr.Tech., M.Sc.) works as a Senior Researcher at the Department of Industrial Management, Tampere University of Technology, Finland. Kujansivu has ten years of research experience on the measurement and management of organizations' intellectual capital and business performance. Kujansivu's research has previously been published in, e.g. International Journal of Learning and Intellectual Capital, International Journal of Services Technology and Management, Production Planning \& Control and Measuring Business Excellence. In addition, she has written practical books on those research topics. Kujansivu also acts as the Managing Partner of Prodia Ltd.

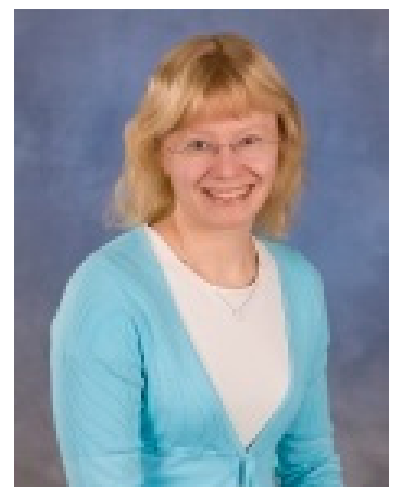

Satu Parjanen (M.Soc.Sc.) is a researcher at LUT Lahti School of Innovation, Finland. Her research interests are related to brokerage functions and distances as sources of innovation. The theme of her post-graduate studies is collective creativity in practice-based innovation. She has published, for example, in Interdisciplinary Journal of Information, Knowledge and Management and International Journal of Innovation and Learning. 